Sign Systems Studies 46(4), 2018, 630-639

\title{
Two decades of ecosemiotics in Tartu
}

\section{Timo Maran ${ }^{1}$}

This paper aims to provide an overview of ecosemiotics (or semiotic ecology) particularly as developed at the University of Tartu (Estonia) and adjacent academic communities. The first ecosemiotic publications were issued in Tartu in 1998 and thus the history of the field now reaches back two decades. The rationale of the paper is twofold: to preserve the record of the activities of Tartu's ecosemiotics and to publicize the paradigm in the context of contemporary environmental humanities. Its emergence and development being closely bound to the scholars in Tartu, ecosemiotics is now a well-established theory of its own. In the following I present the main events, where the University of Tartu was involved, which facilitated this theoretical development.

Ecosemiotics studies semiosic or sign-mediated aspects of ecology (including relations between human culture and the environment). ${ }^{2}$ It has been defined as "the study of sign processes which relate organisms to their natural environment" (Nöth 2001: 71) or as the semiotic discipline investigating "human relationships to nature which have a semiosic (sign-mediated) basis" (Kull 1998: 351). This means that ecosemiotics is one of the semiotic theories that extends the scope of a central concept of semiotics - the sign (understood as a mediated relation) - from human culture to other species and, particularly, to ecological systems. More recently, we have specified ecosemiotics to be "a branch of semiotics that studies sign processes as responsible for ecological phenomena" (Maran, Kull 2014: 41). The concern of ecosemiotics may be considered to lie with the semiotic processes that relate to or address the broader context of living biological processes (Maran 2017a: 5).

The beginning of ecosemiotics in Tartu can be marked by two influential papers published in the journal Sign Systems Studies issued by the University of Tartu Press: "Ecosemiotics" (Nöth 1998) and "Semiotic ecology: Different natures in the semiosphere" (Kull 1998) (for a detailed overview of the history of ecosemiotic events and activities in Tartu, see Table 1). Collaboration between Kalevi Kull

1 Author's address: Department of Semiotics, University of Tartu, Jakobi 2, 51005 Tartu, Estonia; e-mail: timo.maran@ut.ee.

2 For the overview of the history of the concept, see Maran, Kull 2015. 
and Winfried Nöth led to the organization of the first international meeting on ecosemiotics in 2000, that took place in the International Semiotics Institute with several Estonian scholars participating (Nöth, Kull 2000a, 2000b), and a special issue of Sign Systems Studies given out jointly with Kassel University Press (Nöth, Kull 2001). In 2001 the series of Ecosemiotic Summer Seminars started. Since then, this series, organized mostly by and for the students of the University of Tartu, both in English and in Estonian, has annually taken place in various locations in Estonia (see Table 2). In 2002, these initiating events were followed by introducing ecosemiotic courses into the curricula of several degrees offered by the University of Tartu's Department of Semiotics, and by successfully applying for research grants to support research projects on ecosemiotics. The main initiator of these and many other ecosemiotic activities in Tartu has been Kalevi Kull, professor of biosemiotics. More recently, special issues of the journals Sign Systems Studies and Biosemiotics as well as edited collections on ecosemiotic topics have been published by the University of Tartu Press, the Estonian Literary Museum, and internationally by Springer and Rodopi. The fact that in the last decade five doctoral dissertations connected to ecosemiotics have been defended at the Department of Semiotics, University of Tartu testifies to the maturation of the paradigm. Also, in 2013, the first international research project on an ecosemiotic subject matter, "Animals in changing environments: Cultural mediation and semiotic analysis" was launched in collaboration between the University of Tartu and the University of Stavanger, Norway.

Ecosemiotics can be seen as a place-specific paradigm connected to the academic atmosphere and genius loci of Tartu. It has multiple roots and precursors that have been combined and elaborated in Tartu into distinctive conceptual syntheses. The broader theoretical bases on which ecosemiotics relies is the combination of Jakob von Uexküll's umwelt theory (Uexküll 2010) and Juri Lotman's semiotics of culture (Lotman 1990). Some other direct influences include the environmental semiotics of the German tradition (works of Winfried Nöth, Martin Krampen, Ronald Posner), Norwegian environmental philosophy (most notably Arne Næss, who visited Tartu in 199833), the Russian/ Soviet community ecology (Viktor Masing, Alexander Levich - on this, see Kull 2016a) and biosemiotic studies in general (especially works of Jesper Hoffmeyer, Wendy Wheeler, Andreas Weber, Almo Farina). More recently, traces of French science and technology studies (Bruno Latour, see Maran 2015) are evident, as well as topics common with phenomenology (Magnus, Kull 2012; Tønnessen

3 This connection is well exemplified by the Tartu interpretation of Næss' deep ecology platform - see Kull 2011. 
2011), aesthetics (Kull 2016b), translation studies (Kull, Torop 2003) and cultural geography (Lindström et al. 2011) can be noticed. These influences suggest that Tartu-originating ecosemiotics belongs to the continental tradition. Ecosemiotics is more analytical and theory-related than many critically oriented (especially Anglo-American) schools of environmental humanities.

Describing the history and the development of this vivid academic paradigm is a challenge, as it might easily become the author's attempt to display its heritage or to shape its future. What can be safely achieved, however, is presenting the paradigm through some of the concepts proposed by scholars active in Tartu's ecosemiotics. As in semiotics in general, well-organized systems of concepts can be seen as a main methodological tool to approach specific research objects. A few of such ecosemiotic concepts are: distinction of $0 / 1 / 2 / 3$ natures (Kalevi Kull), umwelt transition (Morten Tønnessen), biotranslation (Kalevi Kull, Peeter Torop), naturetext (Timo Maran, Kadri Tüür), herbal landscape (Renata Sõukand), consortium (Kalevi Kull), ecological code (Kalevi Kull, Timo Maran), environmental metasign (Jamie L. Kruis, Timo Maran), semiocide (Ivar Puura) - for definitions and sources, see Table 3. What appears to be specific about these concepts is that they all describe distinctions, similarities, intermediate stages, contentions or entanglements of nature-cultures. Further, all these concepts are dynamical and processual.

Employing these concepts, the theoretical core of Tartu-originating ecosemiotics appears to be the analysis of both semiotic bonds in ecosystems and signbased representations of nature in human culture(s) within the same disciplinary framework. Semiotic processes in nature and culture are seen as interconnected, while at the same time the difference in the level of complexity between cultural symbolic and pre-linguistic sign processes is acknowledged. In this framework, both human and non-human living beings are viewed as active subjects, each perceiving and acting through their own species-specific umwelts (Magnus, Kull 2012). The main focus of such analysis appears to be located in sign-based influences, that is, effects and transmissions between different complexity levels in nature-cultures. These connections are often revealed in specific case studies concerning, e.g., urban vegetation (Magnus, Remm 2018), zoological gardens (Mäekivi 2017, 2018), novel species (Maran 2015).

Tartu's ecosemiotics has been a relatively loosely organized network of institutions and people. The Department of Semiotics at the University of Tartu has been acting as a central hub of research and publishing, while the Estonian Naturalists' Society, with its branch, the Jakob von Uexküll Centre, has been playing an important role in organizing public seminars. There has also been cooperation with other institutions, such as the Estonian Literary Museum; the 
Centre for Landscape and Culture, and the Centre for Environmental History at Tallinn University; the University of Stavanger (Norway); and the International Semiotics Institute (Imatra, Kaunas). Notably, the involvement and activities of students (e.g. Riste Keskpaik, Kaie Kotov, Nelly Mäekivi) has been influential in shaping Tartu's ecosemiotics. Over the years, several former students (e.g. Renata Sõukand, Morten Tønnessen, Riin Magnus, Kadri Tüür, Kati Lindström) have become established researchers who continue to carry on and elaborate the ecosemiotic tradition.

Due to its strong scholarly tradition, robust methodological apparatus and systemic approach to nature-culture, ecosemiotics has a good potential to be a part of and to contribute to the building of the contemporary environmental humanities ${ }^{4}$.

Table 1. Events and activities in Tartu's ecosemiotics

\begin{tabular}{|c|c|}
\hline 1998 & $\begin{array}{l}\text { - Papers "Ecosemiotics" (Winfried Nöth) and "Semiotic ecology: Different natures } \\
\text { in the semiosphere" (Kalevi Kull) published in Sign Systems Studies (vol. 28). } \\
\text { - Workshop "Uses of Nature: Towards an Anthropology of the Environment" } \\
\text { (Tartu, 10-14 May 1998; Tim Ingold visits Tartu). } \\
\text { - Arne Næss visits Tartu (8-10 October1998). }\end{array}$ \\
\hline 1999 & $\begin{array}{l}\text { - Seminar "Kultuur ja loodus" [Culture and Nature] (Palmse, 7-8 August 1999; } \\
\text { Sigmund Kvaløy Setreng takes part in the event). }\end{array}$ \\
\hline 2000 & $\begin{array}{l}\text { - Edited collection Tekst ja loodus [Text and Nature] (Maran, Timo; Tüür, Kadri, } \\
\text { eds.; Eesti Kirjanduse Selts 2000). }\end{array}$ \\
\hline 2001 & $\begin{array}{l}\text { - First Ecosemiotics Summer Seminar "Eesti loodus mõt(t)e viisid” ["Modes of } \\
\text { Estonian Nature Thought"] (Lõetsa, Muhu, } 29 \text { June - 1 July 2001; the series has } \\
\text { been organized annually ever since, see Table 2). } \\
\text { - A special issue of Sign Systems Studies on semiotics of nature (vol. } 29.1 \text { Nöth, } \\
\text { Winfried; Kull, Kalevi, eds.). }\end{array}$ \\
\hline 2002 & $\begin{array}{l}\text { - First research grant on ecosemiotics awarded by the Estonian Science Foundation } \\
\text { "The outlines of the ecological dimension of semiotics and the analysis of } \\
\text { Estonian examples" (2002-2005; Principal Investigator Kalevi Kull, Department } \\
\text { of Semiotics, University of Tartu). } \\
\text { - The course "Ecosemiotics" is taught at the Department of Semiotics, University } \\
\text { of Tartu, for the first time (the course has been a part of the BA curriculum of } \\
\text { Semiotics and Culture Studies up to today). }\end{array}$ \\
\hline
\end{tabular}

4 Acknowledgements: I am grateful to Kalevi Kull for information on the Ecosemiotic Summer Seminars series. The research for this article was supported by the institutional research grant IUT2-44 and by the individual research grant PUT1363 "Semiotics of multispecies environments: Agencies, meaning making and communication conflicts" from the Estonian Research Council. 


\begin{tabular}{|c|c|}
\hline 2003 & $\begin{array}{l}\text { - Monthly seminar series “Personal Natures” [Isiklikud loodused] at the Estonian } \\
\text { Naturalists' Society (Tartu). }\end{array}$ \\
\hline 2004 & $\begin{array}{l}\text { - Conference "Culture, Nature, Semiotics: Locations IV" (Tartu-Tallinn, 23-26 } \\
\text { August } 2004 \text { organized jointly by the Department of Semiotics at the University } \\
\text { of Tartu, the Estonian Literary Museum, and the Estonian Academy of Arts). } \\
\text { - "The Tartu ecosemiotic principles of deep ecology" inspired by works of Arne } \\
\text { Naess formulated by Kalevi Kull, Riste Keskpaik, Kaie Kotov (see Kull 2011). }\end{array}$ \\
\hline 2005 & $\begin{array}{l}\text { - Edited volume Eesti looduskultuur [Estonian Nature-Culture] (Maran, Timo; Tüür, } \\
\text { Kadri, eds.; Estonian Literary Museum 2005). }\end{array}$ \\
\hline 2008 & $\begin{array}{l}\text { - Seminar "What's Wrong with Nature? An Interdisciplinary Seminar Investigating } \\
\text { Human Perceptions of Nature and Environmental Change" (Tartu, 25-26 January } \\
\text { 2008). }\end{array}$ \\
\hline 2009 & $\begin{array}{l}\text { - Workshop “The Semiotics/Phenomenology of Perception" (Tartu, 6-7 February } \\
\text { 2009, David Abram participates in the event). } \\
\text { - Conference "Spatiality, Memory and Visualization of Culture/Nature } \\
\text { Relationships: Theoretical Aspects" (Tallinn, 22-24 November 2009, organized } \\
\text { by the Centre of Excellence in Cultural Theory, CECT, where Department of } \\
\text { Semiotics, University of Tartu is a project partner). } \\
\text { - The course "Landscape Semiotics" taught at the Department of Semiotics for the } \\
\text { first time (was part of the MA curriculum in Semiotics, University of Tartu up to } \\
\text { 2016). } \\
\text { - The course "Ecosemiotics: Cultural Interpretations of Nature" taught at the } \\
\text { Department of Semiotics for the first time (the course has been a part of the MA } \\
\text { curriculum of Semiotics and Culture Studies up to today). }\end{array}$ \\
\hline 2010 & $\begin{array}{l}\text { - The special issue of Biosemiotics "Semiotics of Perception" (vol. 3; Tønnessen, } \\
\text { Morten; Lindström, Kati, eds.). } \\
\text { - PhD thesis related to ecosemiotics Herbal Landscape (Renata Sõukand) defended } \\
\text { at the Department of Semiotics, University of Tartu. }\end{array}$ \\
\hline 2011 & $\begin{array}{l}\text { - Edited collection The Space of Culture - The Place of Nature in Estonia and Beyond } \\
\text { (Peil, Tiina, ed.; University of Tartu Press 2011) } \\
\text { - PhD theses related to ecosemiotics defended at the Department of Semiotics, } \\
\text { University of Tartu: Delineating Landscape Semiotics. Towards the Semiotic Study } \\
\text { of Landscape Processes (Kati Lindström) and Umwelt Transition and Uexküllian } \\
\text { Phenomenology: An Ecosemiotic Analysis of Norwegian Wolf Management (Morten } \\
\text { Tønnessen). }\end{array}$ \\
\hline 2013 & $\begin{array}{l}\text { - Research grant "Animals in changing environments: Cultural mediation and } \\
\text { semiotic analysis" (2013-2016, Principal Investigator Timo Maran, Department } \\
\text { of Semiotics, University of Tartu, in collaboration with Morten Tønnessen, } \\
\text { University of Stavanger, Norway). } \\
\text { - Seminar "Methodology of Ecosemiotics" (Tartu, 28-29 November 2013). }\end{array}$ \\
\hline \begin{tabular}{|l|}
2014 \\
\end{tabular} & $\begin{array}{l}\text { - Edited volume The Semiotics of Animal Representations (Tønnessen, Morten; } \\
\text { Tüür, Kadri, eds.; Rodopi 2014). } \\
\text { - Conference "Framing Nature: Signs, Stories, and Ecologies of Meaning" (Tartu, } \\
29 \text { April-3 May 2014, in cooperation between the Department of Semiotics, } \\
\text { University of Tartu, the Nordic Network for Interdisciplinary Environmental Studies } \\
\text { (NIES) and the European Association for the Study of Literature, Culture and } \\
\text { Environment (EASLCE)). }\end{array}$ \\
\hline
\end{tabular}




\begin{tabular}{|l}
\hline 2015 - Seminar "Communication in Nature Protection and Zoological Gardens" \\
[Kommunikatsioon looduskaitses ja loomaaias] (Tallinn, 20-21 October 2015, in \\
cooperation between the Department of Semiotics, University of Tartu, and the \\
Tallinn Zoological Gardens). \\
- The course "Semiotic Analysis of Environment" taught at the Department \\
of Semiotics, University of Tartu, for the first time (has been a part of MA \\
curriculum in Semiotics up to today). \\
\hline 2016 - Special issue of Sign Systems Studies, Framing Nature and Culture (vol. 44.1/2; \\
Linask, Lauri; Magnus, Riin, eds.). \\
- "Seminar on Nature-Cultures: Protected Areas" [Looduskultuuri seminar: \\
kaitsealad] (Tallinn, 23-24 March 2017, in collaboration between the Department \\
of Semiotics at the University of Tartu and the Tallinn Zoological Gardens). \\
- PhD thesis related to ecosemiotics Semiotics of Nature Representations: On the \\
Example of Nature Writing (Kadri Tüür). \\
- Research project "Semiotics of Multispecies Environments: Agencies, Meaning \\
Making and Communication Conflicts" launched (2017-2020; allocated by the \\
Estonian Research Agency, Principal Investigator Timo Maran). \\
- Seminar "Multispecies City: Diversity, Communication, Conflicts" (Tartu, 1-2 \\
December 2017) \\
- "Seminar on Nature-Cultures: Messages of Nature Protection" [Looduskultuuri \\
seminar: Loodushoiu sõnumid] (Tallinn, 22-23 March 2018, in collaboration \\
between the Department of Semiotics, University of Tartu, and the Tallinn \\
Zoological Gardens). \\
- Conference "Semiotics of Hybrid Natures: Anthropogenic Ecosystems, \\
Multimodalities, Transformed Umwelts" (Tartu, 8-10 November 2018). \\
- PhD thesis related to ecosemiotics The Zoological Garden as a Hybrid \\
Environment - A (Zoo)Semiotic Analysis (Nelly Mäekivi).
\end{tabular}

Table 2. Ecosemiotic Summer Seminars [Ökosemiootika suveseminarid] (titles given as they appear in the seminar programmes)

\begin{tabular}{|ll|}
\hline 2001 & $\begin{array}{l}\text { First Ecosemiotic Summer Seminar “Eesti loodus mõt(t)e viisid” [Modes of } \\
\text { Estonian Nature Thought] (29 June-1 July 2001, Lõetsa, Muhu) }\end{array}$ \\
\hline 2002 & $\begin{array}{l}\text { Ecosemiotic Summer Seminar “Isiklikud loodused” [Personal Natures] } \\
\text { (23-25 August 2002, Koguva, Muhu) }\end{array}$ \\
\hline 2003 & $\begin{array}{l}\text { Ecosemiotic Summer Seminar “Loomu tuhnimine” [Digging into One’s Nature] } \\
\text { (4-6 July 2003, Kütioru) }\end{array}$ \\
\hline 2004 & IV Ecosemiotic Summer Seminar (6-8 August 2004, Puhtu) \\
\hline 2005 & $\begin{array}{l}\text { Ecosemiotic Summer Seminar “Keskkonnaeetika - mis loom see on?” } \\
\text { [Environmental Ethics - What Beast is That?] (15-17 July 2005, Mõndavere) }\end{array}$ \\
\hline 2006 & $\begin{array}{l}\text { Seminar “Keskkonnaeetika ja loodusfilosoofia” [Environmental Ethics and Nature } \\
\text { Philosophy] (13-14 July 2006, Emajõe Suursoo Keskus) }\end{array}$ \\
\hline 2007 & $\begin{array}{l}\text { Ecosemiotic Summer Seminar “Pahupidi loodus” [Nature Reversed] (17-19 August } \\
\text { 2007, Kohtla-Nõmme) }\end{array}$ \\
\hline 2008 & Ecosemiotic Summer Seminar (3-5 August 2008, Esna) \\
\hline
\end{tabular}




\begin{tabular}{|ll|}
\hline 2009 & Ecosemiotic Summer Seminar (31 July -2 August 2009, Soomaa) \\
\hline 2010 & Ecosemiotic Summer Seminar (10-11 July 2010, Nüpli) \\
\hline 2011 & Ecosemiotic Summer Seminar (28-29 July 2011, Rutja) \\
\hline 2012 & $\begin{array}{l}\text { Ecosemiotic Summer Seminar "Mõtte kohad ja mõttekohad” [Places of Thought } \\
\text { and Places to Think] (3-4 August 2012, Ähijärve) }\end{array}$ \\
\hline 2013 & $\begin{array}{l}\text { Ecosemiotic Summer Seminar "Mõnusad elulaadid" [Good Ways of Living] (7-8 } \\
\text { July 2013, Mustakurmu) }\end{array}$ \\
\hline 2015 & $\begin{array}{l}\text { Ecosemiotic Summer Seminar "Üksik ja üldine loodusmõttes" [The Particular and } \\
\text { the General in Nature Thought] (1-3 August 2014, Jõesuu, Hiiumaa) }\end{array}$ \\
\hline 2016 & $\begin{array}{l}\text { Ecosemiotic Summer Seminar “Semiotics of Anticipation” [Ootuse semiootika] } \\
\text { [Ökoloogiline vaesumine kui tähendus- ja tunnetuskollaps] (9-11 July 2016, Tamse, } \\
\text { Muhu) }\end{array}$ \\
\hline 2018 & $\begin{array}{l}\text { Ecosemiotic Summer Seminar "Normid ja tervis" [Norms and Health] (17-19 } \\
\text { August 2018, Pusi) }\end{array}$ \\
\hline
\end{tabular}

Table 3. Concepts of Tartu ecosemiotics

\begin{tabular}{|c|c|c|}
\hline Concept & Definition & Source \\
\hline $0 / 1 / 2 / 3$ nature & $\begin{array}{l}\text { "Zero nature is nature itself (e.g., absolute wilderness). } \\
\text { First nature is the nature as we see, identify, describe and } \\
\text { interpret it. Second nature is the nature which we have } \\
\text { materially interpreted, this is materially translated nature, } \\
\text { i.e. a changed nature, a produced nature. Third nature is a } \\
\text { virtual nature, as it exists in art and science." }\end{array}$ & $\begin{array}{l}\text { Kull 1998: } \\
355\end{array}$ \\
\hline $\begin{array}{l}\text { umwelt } \\
\text { transition }\end{array}$ & $\begin{array}{l}\text { "An Umwelt transition can be defined as a lasting, } \\
\text { systematic change, within the life cycle of a being, } \\
\text { considered from an ontogenetic (individual), phylogenetic } \\
\text { (population-, species-) or cultural perspective, from one } \\
\text { typical appearance of its Umwelt to another." }\end{array}$ & $\begin{array}{l}\text { Tønnessen } \\
\text { 2010: } 383\end{array}$ \\
\hline biotranslation & $\begin{array}{l}\text { "[...] some signs in one Umwelt are put into a correspon- } \\
\text { dence with some signs in another Umwelt." } \\
\text { "For it to be possible for translation to occur, there must } \\
\text { be a certain connection, or overlapping, between the } \\
\text { Umwelten." }\end{array}$ & $\begin{array}{l}\text { Kull, Torop } \\
\text { 2003: } 318\end{array}$ \\
\hline nature-text & $\begin{array}{l}\text { "[...] nature-text can be understood as a set of physically } \\
\text { justified meaning connections between text written in a } \\
\text { conventional language and the natural environment." } \\
\text { "[...] the nature-text model asks what kind of literary } \\
\text { devices are there to convey what kind of human- } \\
\text { environment relation (message) in the context of what kind } \\
\text { of environment." }\end{array}$ & $\begin{array}{l}\text { Maran 2007: } \\
281 \\
\text { Maran, Tüür } \\
\text { 2016: } 290\end{array}$ \\
\hline
\end{tabular}




\begin{tabular}{|c|c|c|}
\hline $\begin{array}{l}\text { herbal } \\
\text { landscape }\end{array}$ & $\begin{array}{l}\text { "A cognitive field associated with plants used to treat or } \\
\text { prevent diseases, established within specific cultural and } \\
\text { climatic zones either personal or shared within a certain } \\
\text { group of people." }\end{array}$ & $\begin{array}{l}\text { Sõukand } \\
\text { 2010: } 27\end{array}$ \\
\hline consortium & $\begin{array}{l}\text { "Consortium can therefore be defined as a group of } \\
\text { organisms connected via (sign) relations." }\end{array}$ & $\begin{array}{l}\text { Kull 2010: } \\
351\end{array}$ \\
\hline $\begin{array}{l}\text { ecological } \\
\text { code }\end{array}$ & $\begin{array}{l}\text { "[...] the sets of (sign) relations (regular irreducible } \\
\text { correspondences) characteristic of an entire ecosystem, } \\
\text { including the interspecies relations in particular." } \\
\text { "[...] meaning structures in nature that surpass the limits } \\
\text { of one species and thereby organise species relations in } \\
\text { ecosystems." }\end{array}$ & $\begin{array}{l}\text { Maran 2017a: } \\
128\end{array}$ \\
\hline $\begin{array}{l}\text { environmental } \\
\text { meta-signs }\end{array}$ & $\begin{array}{l}\text { "[...] signs that operate on a more general level, influencing } \\
\text { the interpretation space of any singular environmental sign } \\
\text { in the sign field." } \\
\text { "[...] meta-sign is based on repetition of a significant } \\
\text { change in the environment, which has been dealt with in } \\
\text { landscape studies in terms of rhythms or seasonality." }\end{array}$ & $\begin{array}{l}\text { Maran 2017b: } \\
364 \\
\text { Kruis 2017: } \\
250\end{array}$ \\
\hline semiocide & $\begin{array}{l}\text { "I understand semiocide to be a situation in which signs } \\
\text { and stories that are significant for someone are destroyed } \\
\text { because of someone else's malevolence or carelessness, } \\
\text { thereby stealing a part of the former's identity." }\end{array}$ & $\begin{array}{l}\text { Puura } 2013 \\
\text { (2002): } 152\end{array}$ \\
\hline
\end{tabular}

\section{References}

Kruis, Jamie L. 2017. Shoshone as a text: A structural-semiotic analysis of reading the river as a whitewater raft guide. In: Kannike, Anu; Tasa, Monika; Västrik, Ergo-Hart (eds.), Body, Personhood and Privacy: Perspectives on the Cultural Other and Human Experience. (Approaches to Culture Theory 7.) Tartu: University of Tartu Press, 245-265.

Kull, Kalevi 1998. Semiotic ecology: Different natures in the semiosphere. Sign Systems Studies 26: 344-371.

- 2010. Ecosystems are made of semiosic bonds: Consortia, umwelten, biophony and ecological codes. Biosemiotics 3(3): 347-357.

- 2011. Foundations for ecosemiotic deep ecology. In: Peil, Tiina (ed.), The Space of Culture the Place of Nature in Estonia and Beyond. (Approaches to Culture Theory 1.) Tartu: Tartu University Press, 69-75.

- 2016a. Alexandr Levich (1945-2016) and the Tartu-Moscow biosemiotic nexus. Sign Systems Studies 44(1/2): 255-266.

- 2016b. Ecosemiotics of art: Whether nature may be beautified. In: Allora, Jennifer; Calzadilla, Guillermo (eds.), Puerto Rican Light (Cueva Vientos). New York: Dia Art Foundation, 99-105.

Kull, Kalevi; Torop, Peeter 2003. Biotranslation: Translation between umwelten. In: Petrilli, Susan (ed.), Translation Translation. (Approaches to Translation Studies 21.) Amsterdam: Rodopi, 313-328. 
Lindström, Kati 2011. Delineating Landscape Semiotics: Towards the Semiotic Study of Landscape Processes. (Dissertationes semioticae Universitatis Tartuensis 15.) Tartu: Tartu University Press.

Lindström, Kati; Kull, Kalevi; Palang, Hannes 2011. Semiotic study of landscapes: An overview from semiology to ecosemiotics. Sign Systems Studies 39(2/4): 12-36.

Lotman, Juri 1990. Universe of the Mind: A Semiotic Theory of Culture. London: I. B. Tauris \& Co.

Magnus, Riin; Kull, Kalevi 2012. Roots of culture in the umwelt. In: Valsiner, Jaan (ed.), The Oxford Handbook of Culture and Psychology. Oxford: Oxford University Press, 649-661.

Magnus, Riin; Remm, Tiit 2018. Urban ecosemiotics of trees: Why the ecological alien species paradigm has not gained ground in cities? Sign Systems Studies 46(2/3): 319-342.

Maran, Timo 2007. Towards an integrated methodology of ecosemiotics: The concept of naturetext. Sign Systems Studies 35(1/2): 269-294.

- 2015. Emergence of the "howling foxes": A semiotic analysis of initial interpretations of the golden jackal (Canis aureus) in Estonia. Biosemiotics 8(3): 463-482.

- 2017a. Mimicry and Meaning: Structure and Semiotics of Biological Mimicry. (Biosemiotics 16.) Berlin: Springer.

- 2017b. On the diversity of environmental signs: A typological approach. Biosemiotics 10(3): 355-368.

Maran, Timo; Kull, Kalevi 2014. Ecosemiotics: Main principles and current developments. Geografiska Annaler: Series B, Human Geography 96(1): 41-50.

Maran, Timo; Tüür, Kadri (eds.) 2000. Tekst ja loodus [Text and Nature]. Tartu: Eesti Kirjanduse Selts.

- (eds.) 2005. Eesti looduskultuur [Estonian Nature-Culture]. Tartu: Eesti Kultuuriloo ja Folkloristika Keskus, Eesti Kirjandusmuuseum.

- 2017. From birds and trees to texts: An ecosemiotic look at Estonian nature writing. In: Parham, John; Westling, Louise (eds.), A Global History of Literature and the Environment. Cambridge: Cambridge University Press, 286-300.

Mäekivi, Nelly 2016. Communication in the study of zoological gardens. In: Maran, Timo; Tønnessen, Morten; Rattasepp, Silver (eds.), Animal Umwelten in a Changing World: Zoosemiotic Perspectives. (Tartu Semiotics Library 18.) Tartu: Tartu University Press, 204-221.

- 2018. The Zoological Garden as a Hybrid Environment: A (Zoo)Semiotic Analysis. (Dissertationes semioticae Universitatis Tartuensis 29.) Tartu: University of Tartu Press.

Nöth, Winfried 1998. Ecosemiotics. Sign Systems Studies 26: 332-343.

- 2001. Ecosemiotics and the semiotics of nature. Sign Systems Studies 29(1): 71-81.

Nöth, Winfried; Kull, Kalevi 2000a. Ein Workshop zur Semiotik der Mensch-UmweltBeziehungen. Zeitschrift für Semiotik 22(3/4): 479-480.

- 2000b. Discovering ecosemiotics. Sign Systems Studies 28: 421-424.

- 2001. Introduction: Special issue on semiotics of nature. Sign Systems Studies 29(1): 9-11.

Peil, Tiina (ed.) 2011. The Space of Culture - The Place of Nature in Estonia and Beyond. (Approaches to Culture Theory 1.) Tartu: University of Tartu Press.

Puura, Ivar 2013. Nature in our memory. Sign Systems Studies 41(1): 150-153. [Translation of: Puura, Ivar 2002. Loodus meie mälus. Eesti Loodus 11: 24-25.] 
Sõukand, Renata 2010. Herbal Landscape. (Dissertationes semioticae Universitatis Tartuensis 14.) Tartu: University of Tartu Press.

Tønnessen, Morten 2010. Steps to a semiotics of being. Biosemiotics 3(3): 375-392.

- 2011. Umwelt Transition and Uexküllian Phenomenology: An Ecosemiotic Analysis of Norwegian Wolf Management. (Dissertationes semioticae Universitatis Tartuensis 16.) Tartu: University of Tartu Press.

Tønnessen, Morten; Tüür, Kadri (eds.) 2013. The Semiotics of Animal Representations. (Nature, Culture, Literature 10.) Amsterdam: Rodopi.

Tüür, Kadri 2017. Semiotics of Nature Representations: On the Example of Nature Writing. (Dissertationes semioticae Universitatis Tartuensis 25.) Tartu: University of Tartu Press.

Uexküll, Jakob von 2010. A Foray into the Worlds of Animals and Humans: With a Theory of Meaning. Minneapolis: University of Minnesota Press. 